\title{
Impact of high temperatures on aluminoceladonite studied by Mössbauer, Raman, X-ray diffraction and X-ray photoelectron spectroscopy
}

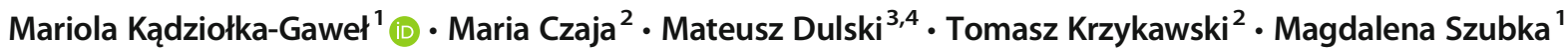

Received: 9 March 2020 / Accepted: 28 April 2021 / Published online: 18 May 2021

(C) The Author(s) 2021

\begin{abstract}
Mössbauer, Raman, X-ray diffraction and X-ray photoelectron spectroscopies were used to examine the effects of temperature on the structure of two aluminoceladonite samples. The process of oxidation of $\mathrm{Fe}^{2+}$ to $\mathrm{Fe}^{3+}$ ions started at about $350{ }^{\circ} \mathrm{C}$ for the sample richer in $\mathrm{Al}$ and at $300{ }^{\circ} \mathrm{C}$ for the sample somewhat lower Al-content. Mössbauer results show that this process may be associated with dehydroxylation or even initiate it. The first stage of dehydroxylation takes place at a temperature $>350^{\circ} \mathrm{C}$ when the adjacent $\mathrm{OH}$ groups are replaced with a single residual oxygen atom. $\mathrm{Up}$ to $\sim 500{ }^{\circ} \mathrm{C}, \mathrm{Fe}$ ions do not migrate from cisoctahedra to trans-octahedra sites, but the coordination number of polyhedra changes from six to five. This temperature can be treated as the second stage of dehydroxylation. The temperature dependence on the integral intensity ratio between bands centered at $\sim 590$ and $705 \mathrm{~cm}^{-1}\left(\mathrm{I}_{590} / \mathrm{I}_{705}\right)$ clearly reflects the temperature at which six-coordinated polyhedra are transformed into five-coordinated polyhedra. X-ray photoelectron spectra obtained in the region of the Si2p, Al2p, Fe2p, K2p and O1s core levels, highlighted a route to identify the position of $\mathrm{Si}, \mathrm{Al}, \mathrm{K}$ and $\mathrm{Fe}$ cations in a structure of layered silicates with temperature. All the measurements show that the sample with a higher aluminum content and a lower iron content in octahedral sites starts to undergo a structural reorganization at a relatively higher temperature than the less aluminum-rich sample does. This suggests that iron may perform an important role in the initiation of the dehydroxylation of aluminoceladonites.
\end{abstract}

Keywords Aluminoceladonite $\cdot$ Temperature effects $\cdot$ Dehydroxylation $\cdot$ Ion-position characterization of isomorphic substitutions $\cdot$ Fe-bearing phyllosilicates

\section{Introduction}

The hydrous layer silicates, commonly known as clay minerals, are widely used in many industrial applications such as paper production, foundries and the chemical- and food

Editorial handling: A. Beran

Mariola Kądziołka-Gaweł

mariola.kadziolka-gawel@us.edu.pl

1 Institute of Physics, University of Silesia, 75 Pułku Piechoty 1, 41-500 Chorzów, Poland

2 Faculty of Earth Sciences, University of Silesia, Będzińska 60, 41-200 Sosnowiec, Poland

3 Institute of Materials Engineering, University of Silesia, 75 Pułku Piechoty 1a, 41-500 Chorzów, Poland

4 Silesian Center for Education and Interdisciplinary Research, 75 Pułku Piechoty 1a, 41-500 Chorzów, Poland industries (Hradila et al. 2003; Murad and Fabris 2010; Moretto et al. 2011). A 2:1 layer is the basic structural unit of various 2:1 phyllosilicates. It consists of an edge-sharing octahedral sheet sandwiched by two corner-sharing tetrahedral sheets. In general, the octahedral sheet of a 2:1 layer contains three symmetrically independent sites differing in the mutual arrangement of $\mathrm{OH}$ groups and oxygen atoms coordinating octahedral cations. The unit cell contains two symmetrically independent octahedral, i.e., one trans-ostahedra (M1) and one cis-octahedra (M2) differing in the positions of $\mathrm{OH}$ groups. The adjacent cis-octahedra share an edge formed by two $\mathrm{OH}$ groups whereas, in trans-octahedra, hydroxyls are located opposite to each other (Muller et al. 1999; Zviagina et al. 2007).

The thermal behavior and related process of dehydroxylation of dioctahedral silicates has been the subject of many investigations (Tsipursky et al. 1985; Muller et al. 2000a, 2000b, 2000c). Dehydroxylation slightly modifies the coordinates of atoms other than the residual oxygen which replaces 
two hydroxyl groups and is located in the plane of the octahedral cations midway between them. This replacement induces a change of the coordination of the octahedral sheet cations, becoming five instead of six. Also, it has been shown quantitatively that the dehydroxylation of $\mathrm{Fe}, \mathrm{Mg}$-rich dioctahedral micas, when heated, is accompanied by a migration of the octahedral sheet cations from cis to trans-sites (Drits et al. 1995; Muller et al. 1998, 2000c; Dainyak et al. 2006). Generally, on heating phyllosilicates, four different processes may occur separately or concurrently, namely, oxidation of cations, loss of water, migration of cations to different sites and disintegration of the structure. However, many questions still remain unanswered about the coordination of the octahedral cations after dehydroxylation, the details of the reaction mechanism and the fate of dehydroxylates formed in nature.

In this study, X-ray diffraction, X-ray photoelectron spectroscopy, Mössbauer and Raman analysis were used to examine the effects of heating on the structure of Febearing dioctahedral mica. The study tested conclusions about the structure of dehydroxylates and octahedralcation migration in phyllosilicates and attempts a global explanation of the role of the content of $\mathrm{Fe}$ in the octahedral sheet in the dehydroxylation process. Additionally, Xray photoelectron spectroscopy was used as a new tool to visualize cation arrangement in a structure of layer silicates at high temperatures.

\section{Experimental details}

\section{Materials}

Several secondary minerals have been found in the altered volcanic rocks of intermediate to basaltic composition in Lubiechowa near Świerzawa (Sudety Mountains) from which two types of clay mineral were collected from amygdales, one emerald-green, the other of dark-green. Based on electronmicroprobe analyses, calculated formulas for these are $\mathrm{K}_{0.629} \mathrm{Ca}_{0.041}\left(\mathrm{Mg}_{0.545} \mathrm{Fe}^{2+}{ }_{0.180} \mathrm{Mn}_{0.002}\right)\left(\mathrm{Fe}^{3+}{ }_{0.430} \mathrm{Al}_{0.950}\right)(\mathrm{S}-$ i3.755 $\left.\mathrm{Al}_{0.245}\right) \mathrm{O}_{10}(\mathrm{OH})_{2}$ for emerald-green "celadonite" and $\mathrm{K}_{0.766} \mathrm{Ca}_{0.031}\left(\mathrm{Mg}_{0.584} \mathrm{Fe}^{2+}{ }_{0.134} \mathrm{Mn}_{0.001}\right)\left(\mathrm{Fe}^{3+}{ }_{0.562} \mathrm{Al}_{0.655}\right)(\mathrm{S}-$ i3.962 $\left.\mathrm{Al}_{0.038}\right) \mathrm{O}_{10}(\mathrm{OH})_{2}$ for dark-green "celadonite", where $\mathrm{FeO}$ and $\mathrm{Fe}_{2} \mathrm{O}_{3}$ contents were determined by the use of the $\mathrm{Fe}^{3+} / \mathrm{Fe}^{2+}$ values obtained from Mössbauer spectra. According to criteria for the classification of clay minerals (Rieder et al. 1998; Drits et al. 1997; Tischendorf et al. 2007; Zviagina et al. 2015), the samples cannot be considered celadonite, but aluminoceladonite. Here, they are named as aluminoceladonites $\mathrm{AlCel1}$ and $\mathrm{AlCel}$, respectively. Several types of measurements were performed for the studied samples.

\section{X-ray diffraction}

In-situ, high-temperature X-ray diffraction (XRD) measurements were performed by $\mathrm{CuK}_{\alpha}$ radiation using a PANalytical, X'Pert Pro Multi-Purpose Diffractometer with a Philips PW3040/60 X-ray generator and an Anton Paar HTK-16 thermal chamber. A nickel filter was placed in the diffracted-beam path to reduce the $\mathrm{K}_{\beta}$ radiation. XRD patterns were collected in the range $4^{\circ} 2 \theta$ to $90^{\circ} 2 \theta$ with a step size of $0.01^{\circ} 2 \theta$ and nominal time per step of $300 \mathrm{~s}$, with the aid of a scanning $X^{\prime}$ Celerator detector (with an active length of $\left.2.12^{\circ} 2 \theta\right)$.

\section{Thermal analysis}

The thermogravimetric analyses (TGA) and differential scanning calorimetry (DSC) were performed using the thermal analyzer NETZSCH Jupiter STA 449 F3. The curves were measured in the temperature range $25-800^{\circ} \mathrm{C}$ at a heating rate of $5{ }^{\circ} \mathrm{C} / \mathrm{min}$. The samples (about $25-30 \mathrm{mg}$ aliquots of powder) were measured in $\mathrm{Al}_{2} \mathrm{O}_{3}$ crucibles in a protective argon atmosphere.

\section{${ }^{57}$ Fe Mössbauer spectroscopy}

${ }^{57} \mathrm{Fe}$ Mössbauer transmission spectra were recorded at room temperature using a MS96 spectrometer and a linear arrangement of a ${ }^{57} \mathrm{Co}: \mathrm{Rh}(25 \mathrm{mCi})$ source, a multichannel analyzer, an absorber and a detector. The spectrometer was calibrated at room temperature with a $30 \mu \mathrm{m}$ thick $\alpha$-Fe foil. The samples were pulverized in an agate mortar and heated for $8 \mathrm{~h}$ in air under static conditions in an electric furnace to a variety of temperatures in the range $100-600{ }^{\circ} \mathrm{C}$. After each heating treatment, the Mössbauer measurements were taken. Numerical analysis of the Mössbauer spectra was performed using the WMOSS program (Prisecaru 2009-2016).

\section{Raman spectroscopy}

Raman spectra of the samples were obtained using a WITec confocal Raman microscope CRM alpha 300R equipped with a solid-state laser $(\lambda=532 \mathrm{~nm})$ and a charge-coupled device (CCD) camera. The excitation laser radiation was coupled to the microscope through a single-mode optical fibre with a $50 \mu \mathrm{m}$ diameter. An air Olympus MPLAN (100×/0.90NA) lens was used. The Raman spectra were initially laserexcited for a few hours to eliminate afterglow-type luminescence, and decrease the so-called Raman background effect. The spectrometer monochromator was calibrated using the emission lines of a $\mathrm{Ne}$ lamp. The temperature measurements were performed in-situ using a Linkam heating/cooling stage. The crystals of aluminosilicate were heated at a rate of $5{ }^{\circ} \mathrm{C} /$ min with a temperature accuracy of $0.1{ }^{\circ} \mathrm{C}$ in air. 


\section{X-ray photoelectron spectroscopy}

XPS spectra were obtained using a PHI5700/660 Physical Electronics Photoelectron Spectrometer with monochromatic $\mathrm{Al} \mathrm{K}_{\alpha} \mathrm{X}$-ray radiation $(1486.6 \mathrm{eV})$. The energy of the electrons was measured with a hemispherical analyzer with resolution of about $0.3 \mathrm{eV}$. Photoelectron emission was measured from a surface area with a diameter of $800 \mu \mathrm{m}$ and at a takeoff angle of $45^{\circ}$. Due to the occurrence of a charge effect, a neutralizer was used for nonconductive samples. To determine the binding energy (BE), the $\mathrm{C} 1 \mathrm{~s}$ component was set at $285 \mathrm{eV}$. The solid sample was mounted on a PTS CLEAV RES/C-K sample holder (Prevac Company), cleaved in UHV conditions in a vacuum of about $3 \cdot 10^{-9} \mathrm{Tr}$ and transferred to the XPS chamber. The series of measurements in situ were performed at temperatures of 100,300 and $550{ }^{\circ} \mathrm{C}$. The vacuum in the XPS chamber during the temperature measurements did not exceed $5 \cdot 10^{-8}$ Torr. The increase and stabilization of each temperature was executed over about $30 \mathrm{~min}$ using the Sample Heating Power Supply HEAT2-PS device and controlled by the use of EUROTHERM (Prevac Company). The HEAT2-PS worked in a resistive mode with a ramp of heating current of $1 \mathrm{~A} / \mathrm{min}$.

\section{Results}

\section{X-ray diffraction}

High-temperature XRD patterns (Fig. S1 in the Electronic Supplementary Material (ESM)) were collected every $50{ }^{\circ} \mathrm{C}$ ranging from room temperature to $700{ }^{\circ} \mathrm{C}$ and refined by the use of Rietveld method. Table 1 shows the unit-cell parameters of the investigated samples obtained for the temperature range $<700{ }^{\circ} \mathrm{C}$. The migration of octahedral cations from former cis-octahedra strongly decreases the repulsion between those cations bonded to residual oxygen anions and can be reflected by the temperature-dependence of the $a$ and $b$ parameter values (Table 1; Fig. 1). The decrease of $a$ for AlCel 1 is at $600{ }^{\circ} \mathrm{C}$. For AlCel2, no significant decrease of $a$ can be observed in this temperature region. The minimum values of the $b$ parameters are observed near $650{ }^{\circ} \mathrm{C}$ and indicate that migration of octahedral cations takes place in these wide temperature ranges. Also, with the pure dehydroxylation increases the interlayer thickness, an increase which is reflected in the increase of the $c$ parameter. This rapid increase of this parameter comes after heating at $550{ }^{\circ} \mathrm{C}$ for $\mathrm{AlCel} 1$ and $500{ }^{\circ} \mathrm{C}$ for $\mathrm{AlCel} 2$, which is also confirmed by the variation of the unitcell volume versus temperature (Fig. 1). The relative displacement of the adjacent layers along the $a$ axis is characterized by dependence of the Ic $\cos \beta / a \mathrm{I}$ value on temperature (Fig. 1). The deviation of the observed I $c \cdot \cos \beta / a$ I from the ideal -0.333 value (Drits et al. 2006) depends significantly on the difference in the sizes of the vacant and occupied octahedral site of the 2:1 layer. It is expected that increasing octahedral $\mathrm{Al}$ will be reflected in deviation decreases of the $\mathrm{I} c \cos \beta / a \mathrm{I}$ values. The changes of this value from about 0.363 for the sample of AlCell heated at $550{ }^{\circ} \mathrm{C}$ to 0.303 for that heated at $700{ }^{\circ} \mathrm{C}$, and from 0.367 for the sample of AlCel2 heated at $500{ }^{\circ} \mathrm{C}$ to 0.313 for that heated at $700{ }^{\circ} \mathrm{C}$ also indicate the transformation of cis into trans sites in these temperature ranges. More precisely, the coordination number of polyhedrons change from six into five. Detailed analysis of the unitcell parameters (Table 1; Fig. 1) reveal additional effects which take place near temperatures of $100{ }^{\circ} \mathrm{C}$ and $250{ }^{\circ} \mathrm{C}$ for $\mathrm{AlCel} 2$ and, to a much weaker degree, at $350{ }^{\circ} \mathrm{C}$ for AlCell. Changing values of the $b$ and $I c \cos \beta / a \mathrm{I}$ parameters at $100{ }^{\circ} \mathrm{C}$ can be a result of the loss of bound molecular waters in the structure of the AlCel2. The decrease in unit-cell volume and unit-cell parameters at $350{ }^{\circ} \mathrm{C}$ for AlCell, and at $250{ }^{\circ} \mathrm{C}$ for $\mathrm{AlCel} 2$, can be a result of deprotonation via $\mathrm{Fe}$ oxidation, which reduces the octahedral thickness.

\section{Thermal analysis}

The dehydroxylation temperature can be determined from the DSC-TGA curves, as depicted in Fig. 2. These curves show some thermal movements that occur in the aluminoceladonite samples over a temperature range of $\sim 30^{\circ} \mathrm{C}$ to $800^{\circ} \mathrm{C}$. TGA/ DSC experiments for the investigated aluminoceladonites show that a small loss of $\sim 0.84 \mathrm{wt} \%$ occurs in the temperature range $50-100^{\circ} \mathrm{C}$ for AlCell (Fig. 2a) and $\sim 0.65 \mathrm{wt} \%$ between 50 and $150^{\circ} \mathrm{C}$ for AlCel2 (Fig. 2a). The weight decrease, and the broad endothermic hump between the above temperature ranges, presumably result from the loss of loosely-bound molecular waters. For AlCell, in the temperature ranges 100$550{ }^{\circ} \mathrm{C}$ and $550-780{ }^{\circ} \mathrm{C}$, two areas of weight loss $(3.15 \mathrm{wt} \%$ and $2.55 \mathrm{wt} \%$ ) are observed and indicate the dehydroxylations. The endothermic events that occurred in the ranges $425-567{ }^{\circ} \mathrm{C}$ and $567-675^{\circ} \mathrm{C}$ support this process. In the first region, the main sharp peak is seen at a temperature of $515^{\circ} \mathrm{C}$, preceded by a small peak at $478^{\circ} \mathrm{C}$. This region is deemed the first stage of dehydroxylation. It occurs in a wide temperature range, which is confirmed by a breadth of the endothermic hump which is about $142{ }^{\circ} \mathrm{C}$ wide. In the second temperature range, another endothermic peak related to the second stage of dehydroxylation is visible at $625{ }^{\circ} \mathrm{C}$. For $\mathrm{AlCel} 2$, the dehydroxylations indicated by the mass change of $<5.1 \%$ were detected from 200 to $660{ }^{\circ} \mathrm{C}$. On the DSC curve for $\mathrm{AlCel} 2$, endothermic peaks though visible are not as sharp as for AlCell and appear at different temperatures than for AlCel1. The first peak is visible at $408{ }^{\circ} \mathrm{C}$ and a further two at $484^{\circ} \mathrm{C}$ and $510^{\circ} \mathrm{C}$. For both samples, an endothermic peak was detected at $736^{\circ} \mathrm{C}$. This is probably the temperature at which the decomposition of the aluminoceladonites starts (Savko et al. 2015). 
Table 1 Temperature dependence of unit-cell parameters for the investigated aluminoseladonites calculated from the peak positions of the XRD patterns

\begin{tabular}{|c|c|c|c|c|c|c|c|c|c|c|}
\hline \multirow[b]{2}{*}{$\mathrm{T}\left({ }^{\circ} \mathrm{C}\right)$} & \multicolumn{5}{|l|}{ AlCel1 } & \multicolumn{5}{|l|}{ AlCel2 } \\
\hline & $\mathrm{a}(\AA)$ & $\mathrm{b}(\AA)$ & c $(\AA)$ & $\mathrm{V}\left(\AA^{3}\right)$ & $\beta\left({ }^{\circ}\right)$ & a $(\AA)$ & $\mathrm{b}(\AA)$ & $\mathrm{c}(\AA)$ & $\mathrm{V}\left(\AA^{3}\right)$ & $\beta\left({ }^{\circ}\right)$ \\
\hline 25 & $5.2260(8)$ & $9.0268(9)$ & $10.0993(3)$ & $467.971(2)$ & $100.818(1)$ & $5.2323(9)$ & $9.0360(6)$ & $10.1421(4)$ & $470.782(1)$ & $100.955(8)$ \\
\hline 50 & $5.2262(9)$ & $9.0270(8)$ & $10.1061(2)$ & $468.320(8)$ & $100.814(1)$ & $5.2297(7)$ & $9.0345(1)$ & $10.1507(1)$ & $470.889(6)$ & $100.939(7)$ \\
\hline 100 & $5.2260(8)$ & $9.0276(3)$ & $10.1177(3)$ & $468.860(5)$ & $100.819(2)$ & $5.2300(1)$ & $9.0308(8)$ & $10.1618(2)$ & $471.282(3)$ & $100.910(9)$ \\
\hline 150 & $5.2269(4)$ & $9.0291(9)$ & $10.1289(5)$ & $469.541(3)$ & $100.817(7)$ & $5.2326(2)$ & $9.0351(6)$ & $10.1703(9)$ & $472.052(4)$ & $100.965(1)$ \\
\hline 200 & $5.2286(6)$ & $9.0299(7)$ & $10.1376(9)$ & $470.155(1)$ & $100.809(1)$ & $5.2348(1)$ & $9.0375(7)$ & $10.1794(5)$ & $472.826(6)$ & $100.946(2)$ \\
\hline 250 & $5.2296(5)$ & $9.0326(5)$ & $10.1500(1)$ & $470.956(8)$ & $100.807(4)$ & $5.2326(4)$ & $9.0322(9)$ & $10.1810(7)$ & $472.439(9)$ & $100.940(1)$ \\
\hline 300 & $5.2312(1)$ & $9.0341(1)$ & $10.1615(3)$ & $471.722(1)$ & $100.799(5)$ & $5.2369(2)$ & $9.0372(2)$ & $10.1975(9)$ & $473.870(8)$ & $100.928(4)$ \\
\hline 350 & $5.2303(6)$ & $9.0347(3)$ & $10.1709(4)$ & $472.122(1)$ & $100.794(7)$ & $5.2379(7)$ & $9.0339(9)$ & $10.2073(1)$ & $474.583(5)$ & $100.909(9)$ \\
\hline 400 & $5.2325(2)$ & $9.0359(1)$ & $10.1806(8)$ & $472.834(8)$ & $100.792(4)$ & $5.2367(6)$ & $9.0408(7)$ & $10.2187(9)$ & $475.049(1)$ & $100.918(8)$ \\
\hline 450 & $5.2335(6)$ & $9.0350(1)$ & $10.1900(2)$ & $473.329(4)$ & $100.782(7)$ & $5.2375(9)$ & $9.0342(7)$ & $10.2334(3)$ & $475.467(4)$ & $100.912(8)$ \\
\hline 500 & $5.2344(6)$ & $9.0332(9)$ & $10.2012(9)$ & $473.811(3)$ & $100.804(3)$ & $5.2359(1)$ & $9.0186(1)$ & $10.2444(9)$ & $475.143(8)$ & $100.823(4)$ \\
\hline 550 & $5.2348(6)$ & $9.0245(3)$ & $10.2175(7)$ & $474.257(7)$ & $100.730(9)$ & $5.2366(9)$ & $9.0096(2)$ & $10.3091(3)$ & $478.040(1)$ & $100.633(3)$ \\
\hline 600 & $5.2302(7)$ & $9.0106(4)$ & $10.2619(1)$ & $475.723(9)$ & $100.370(3)$ & $5.2356(8)$ & $9.0001(2)$ & $10.3808(1)$ & $481.598(6)$ & $100.088(3)$ \\
\hline 650 & $5.2269(8)$ & 8.9889(1) & $10.3100(9)$ & $477.903(5)$ & $99.4076(9)$ & $5.2367(7)$ & $8.9922(1)$ & $10.4096(3)$ & $483.256(5)$ & $99.645(4)$ \\
\hline 700 & $5.2215(2)$ & $8.9859(7)$ & $10.3596(4)$ & $480.378(5)$ & $98.783(2)$ & $5.2365(9)$ & $8.9882(8)$ & $10.4021(1)$ & $483.478(2)$ & $99.068(2)$ \\
\hline
\end{tabular}

\section{${ }^{57}$ Fe Mössbauer spectroscopy}

Mössbauer spectra of the initial samples were fitted as a superposition of six doublets, the hyperfine parameters (Table S1 in the ESM) of which indicate iron located only in the octahedral sheet. The initial sample of AlCell contains about $27 \% \mathrm{Fe}^{2+}$ ions. The $\mathrm{Fe}^{3+}$ ions prefer the $c i s-\mathrm{M} 2$ site where $70 \%$ of them are located and the rest are present in trans-M1. In AlCel2, $\mathrm{Fe}^{2+}$ ions constitute $19 \%$ of total iron and are approximately equally divided between two octahedral sites with different local geometric environments around the $\mathrm{Fe}^{2+}$ ions. The hyperfine parameters of the ferric doublets indicate that the majority of the $\mathrm{Fe}^{3+}$ is located in the cis-M2 site in AlCel2. The remainder of these ions are in trans-M1 sites. It should be noted that, the ferrous doublets do not correspond to a specific crystallographic site (M1 or M2), but arise from local geometric and/or electronic distortion environments around the Fe atoms within the octahedral sheet of the micas (Rancourt 1994).

Selected Mössbauer spectra obtained after heating in air at definite temperatures are presented in Figs. 3 and 4. Figure 5 presents the changes in the hyperfine parameters for each component in the AlCel 2 sample after heating at high temperatures. The fact that full line width at half maximum for all components connected with $\mathrm{Fe}^{3+}$ was the same during the fitting procedure for all Mössbauer spectra allows tracking of the changes in hyperfine parameters each component in. The full line width of doublets connected with $\mathrm{Fe}^{2+}$ changed, a change connected with visible changes in a shape of the Mössbauer spectrum and with processes taking place in the aluminoceladonite structure. Due to the dehydration stage, the escape of defects and changes that take place in neighboring octahedral sites, small changes in a shape of the Mössbauer a)

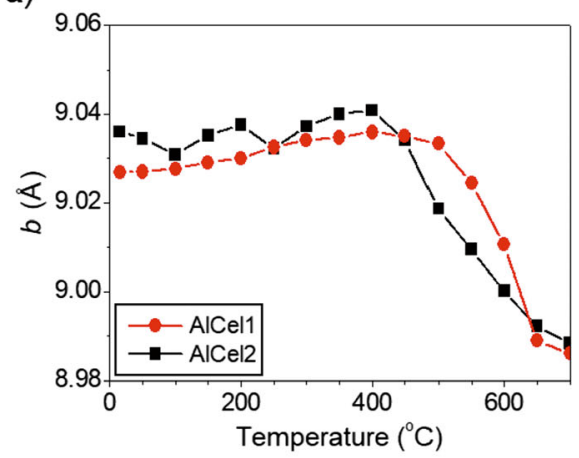

b)

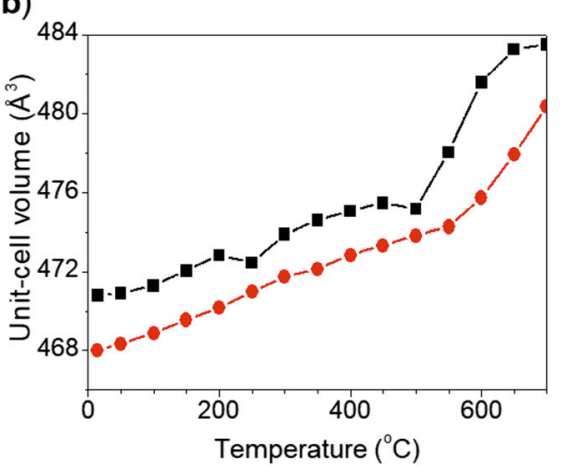

c)

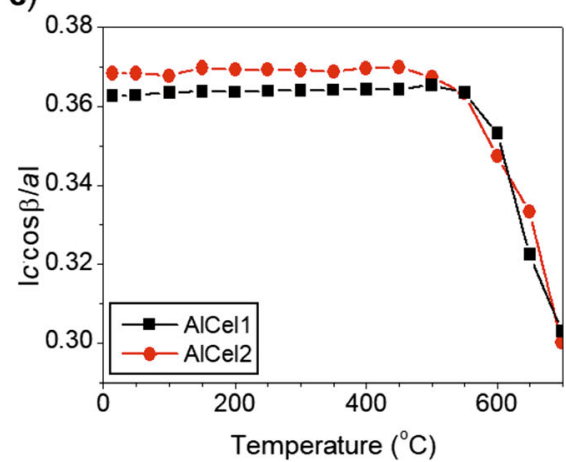

Fig. 1 The temperature-dependence of the a) $b$ parameter, b) unit-cell volume, c) I $c \cdot \cos \beta / a$ I values calculated from the XRD patterns for the investigated aluminoceladonites. The lines indicate the trends of the data and act as a guide to the eye 
Fig. 2 TGA/DTA curve of the investigated a) AlCel1 and b) AlCel2 samples a)

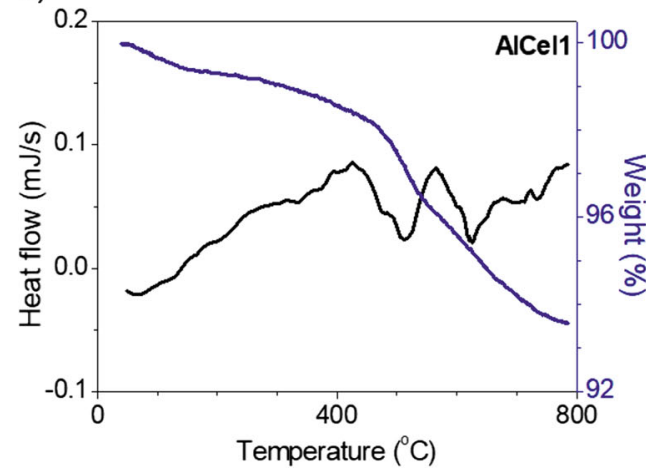

b)

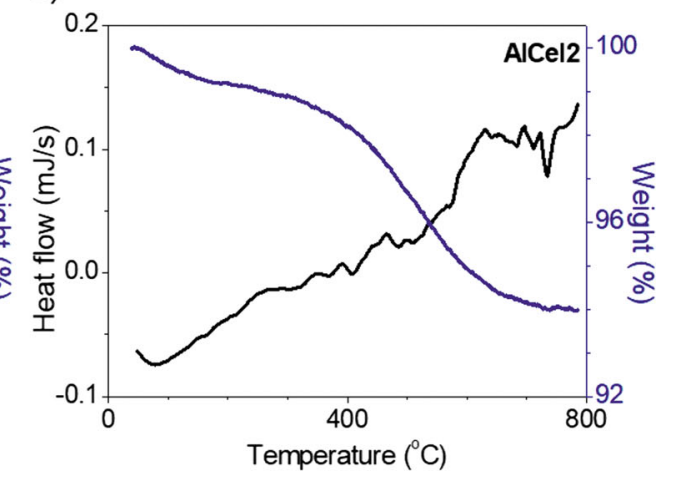

spectra and hyperfine parameters of all components after heating at $100{ }^{\circ} \mathrm{C}$ is seen. After heating at $200^{\circ} \mathrm{C}$, an increase of abundance of $\mathrm{Fe}^{2+}$ that is generated by the presence of structural water is visible. The oxidation of $\mathrm{Fe}^{2+}$ to $\mathrm{Fe}^{3+}$ started at $\sim 350{ }^{\circ} \mathrm{C}$ for AlCell and at $300{ }^{\circ} \mathrm{C}$ for AlCel2. This process took place over a wide temperature range and finished $\sim 150^{\circ} \mathrm{C}$ higher for each aluminoceladonite (Fig. 5). It may be assumed that at a temperature of $\sim 450{ }^{\circ} \mathrm{C}$ for AlCell and $350^{\circ} \mathrm{C}$ for $\mathrm{AlCel} 2$, the first stage of dehydroxylation takes place. Up to a temperature of $\sim 550{ }^{\circ} \mathrm{C}$ for AlCell and $500{ }^{\circ} \mathrm{C}$ for AlCel2, the contribution of components connected with $\mathrm{Fe}^{3+}$ ions in $\mathrm{M} 1$ sites increases rapidly (Fig. 5c). To be precise, the two new doublets represent $\mathrm{Fe}^{3+}$ ions in M1 sites as a result of the decline of those connected with M2. The observed effects on the Mössbauer spectra at these temperatures can be treated as the second stage of dehydroxylation. It is also reflected by the changes in the contribution of $\mathrm{Fe}$ in $\mathrm{M} 1$ and M2 sites versus heating temperature (Fig. $6 a$ and b). The average value of the isomer shifts (IS) in these new doublets is about $0.35 \mathrm{~mm} \mathrm{~s}^{-1}$ and the values of quadrupole splitting (QS) are about $1.65 \mathrm{~mm} \mathrm{~s}^{-1}$ and $2.15 \mathrm{~mm} \mathrm{~s}^{-1}$. The QS parameter does not depend on the total charge at each site but rather on the anisotropy in the charge distribution at the nucleus; the latter parameter increases with increasing octahedral distortion. For this reason, such large QS values indicate redistribution of the octahedral cations over all of the octahedral positions, with the result that the octahedral environments are very distorted. At $550{ }^{\circ} \mathrm{C}$ for $\mathrm{AlCel} 1$ and $500{ }^{\circ} \mathrm{C}$ for $\mathrm{AlCel} 2$ on the Mössbauer spectra (Figs. 2 and 3) and in Table S1 (in the ESM), doublets appear with values of isomer shift of about $0.19 \mathrm{~mm} \mathrm{~s}^{-1}$ and $0.25 \mathrm{~mm} \mathrm{~s}^{-1}$ that are characteristic for $\mathrm{Fe}^{3+}$ in tetrahedral coordination.

\section{Raman spectroscopy}

Raman spectra were collected every $50^{\circ} \mathrm{C}$ ranging from room temperature to $600{ }^{\circ} \mathrm{C}$. Post-processing analysis including baseline and luminescence correction as well as cosmic-ray removal was done using WitecProjectFour, and peak-fitting analysis using the GRAMS software package. Peak fitting was done by means of the Voigt function with a minimum number of components. The spectra of both investigated samples are presented in Fig. 6. In the hydroxyl-stretching range from 3400 to $3700 \mathrm{~cm}^{-1}$, five bands at $3627,3608,3582$, 3564 and $3541 \mathrm{~cm}^{-1}$ for AlCell are seen, and five at 3620 , 3609, 3588, 3567 and $3542 \mathrm{~cm}^{-1}$ for AlCel2 (Fig. 6; Table 2). The two bands with the highest Raman shifts at 3627 and $3620 \mathrm{~cm}^{-1}$ are interpreted as $\mathrm{AlOHAl}$ stretching vibrations. In the light of previous analysis for clay minerals (Zviagina et al. 2004, 2015, 2020), other bands represent $\mathrm{AlMgOH}$, $2 \mathrm{MgOH}, \mathrm{MgFe}^{3+} \mathrm{OH}$ and/or $\mathrm{AlFe}^{2+} \mathrm{OH}$ with a possible contribution from $\mathrm{AlFe}^{3+} \mathrm{OH}$, and $2 \mathrm{Fe}^{3+} \mathrm{OH}$. The temperaturedependent experiment revealed only slight alteration in the band arrangement in the hydroxyl region $\left(3500-3600 \mathrm{~cm}^{-1}\right)$.
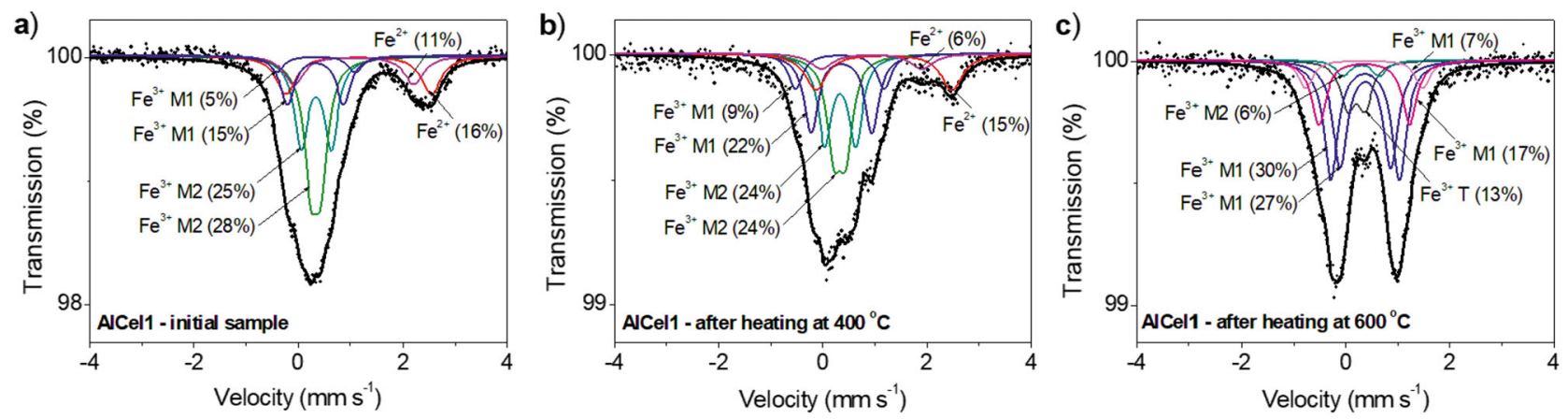

Fig. 3 Room temperature Mössbauer spectra of AlCell obtained for the initial sample a) and after heating in air at temperature b) $400{ }^{\circ} \mathrm{C}$ and c) $600{ }^{\circ} \mathrm{C}$. Quadrupole doublets, their assignment (M1, M2 - octahedral sites, T - dimeric pyramid) and contributions are indicated on the spectra 

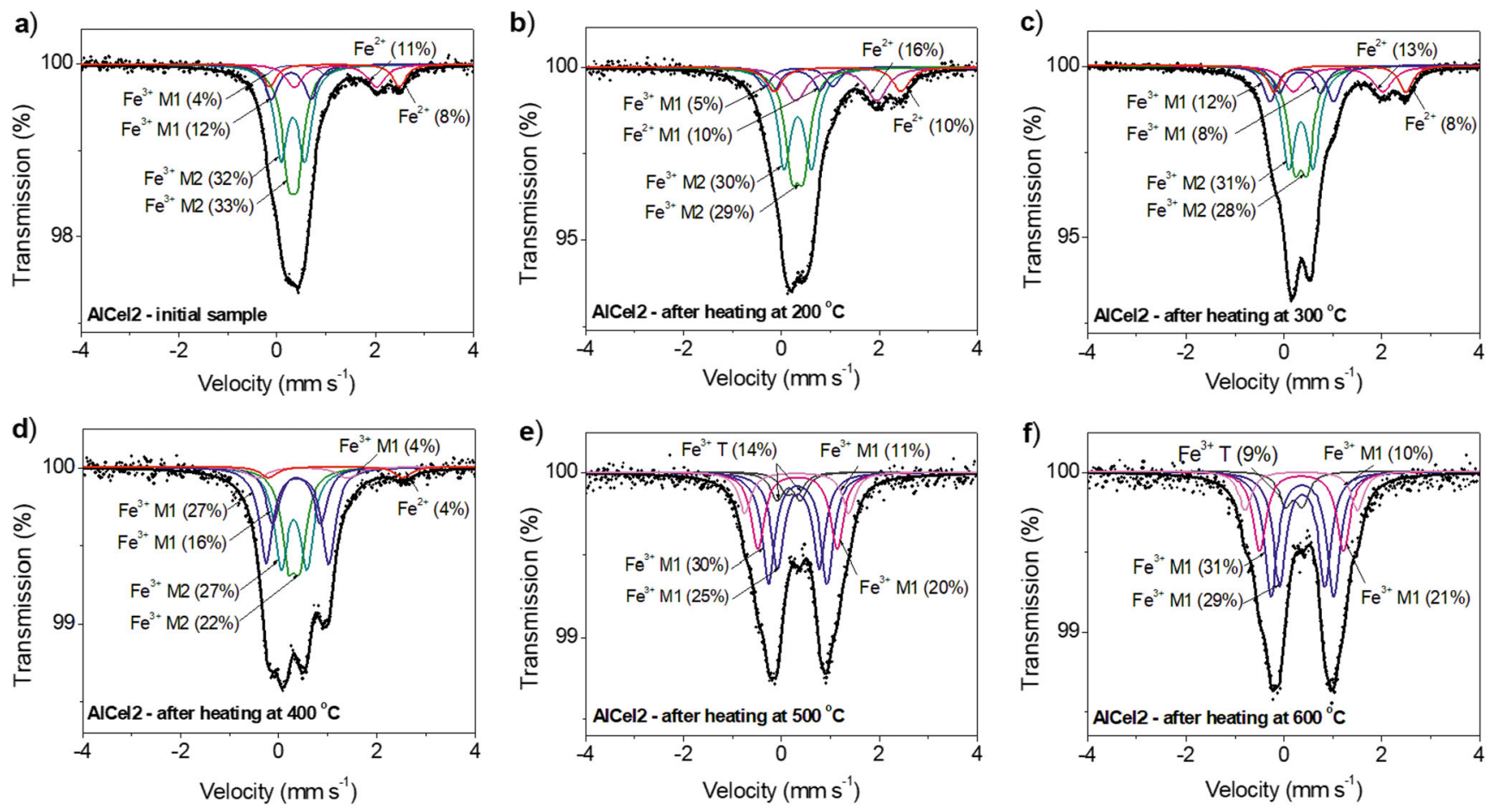

Fig. 4 Room temperature Mössbauer spectra of AlCel2 obtained for a) the initial sample and after heating in air at temperature b) $200{ }^{\circ} \mathrm{C}$, c) $300{ }^{\circ} \mathrm{C}$, d) $400{ }^{\circ} \mathrm{C}$, e) $500{ }^{\circ} \mathrm{C}$ and f) $600{ }^{\circ} \mathrm{C}$. Quadrupole doublets, their

assignment (M1, M2 - octahedral sites, $\mathrm{T}$ - dimeric pyramid) and contributions are indicated on the spectra

The main changes were found to be connected to modification of the band intensity, whereas the band position linked to the vibration of hydroxyl groups at tetrahedral and octahedral units, especially at $\mathrm{MgFe}^{2+} \mathrm{OH}$ or $\mathrm{AlFe}^{2+} \mathrm{OH}, \mathrm{AlFe}^{3+} \mathrm{OH}$, $2 \mathrm{Fe}^{3+} \mathrm{OH}$ and $\mathrm{MgFe}^{3+} \mathrm{OH}$, remained unchanged. Interestingly, temperatures $>500{ }^{\circ} \mathrm{C}$ (AlCell) and $>400{ }^{\circ} \mathrm{C}$ (AlCel2) practically deactivate vibration originating from the $\mathrm{OH}$ modes due to the first stage of dehydroxylation. This effect can also be explained as a result of molecular mobility which, in the case of aluminoceladonite, may lead to the loss of the hydrogen-bonding scheme. This observation is strictly correlated with the analysis of bands ascribed to the stretching vibration within $\left(\mathrm{Al}_{\mathrm{n}} \mathrm{Si}_{4-\mathrm{n}} \mathrm{O}_{10}\right)^{3-}$ units, i.e., in the 1150
$950 \mathrm{~cm}^{-1}$ region (Povarennykh 1978). Here, the intensity of the main bands centered at 1130 and $1083 \mathrm{~cm}^{-1}$ (AlCel1) and at 1144 and $1113 \mathrm{~cm}^{-1}$ (AlCel2) decrease up to $500^{\circ} \mathrm{C}$ and to $400{ }^{\circ} \mathrm{C}$, respectively. With both samples, those bands vanish completely above these temperatures.

The temperature-dependent experiment also revealed a decline in hydrogen bonding strength that may be linked to the molecular re-arrangement within the tetrahedral sheets, including mutual rotation of silica tetrahedra. The reason for this structural reconfiguration is not completely clear, especially in the context of band analysis of this $1150-950 \mathrm{~cm}^{-1}$ region. Therefore, to shed light on this problem, the analyses of the bands located below $950 \mathrm{~cm}^{-1}$ were taken into consideration. a)

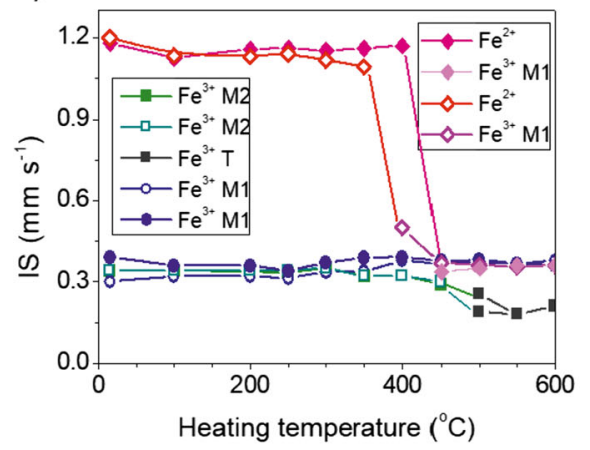

b)

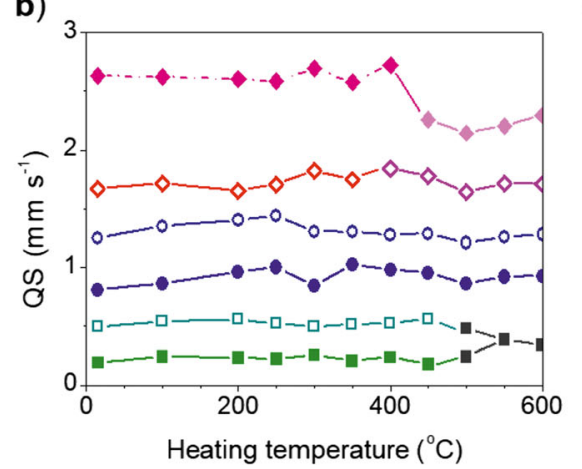

c)

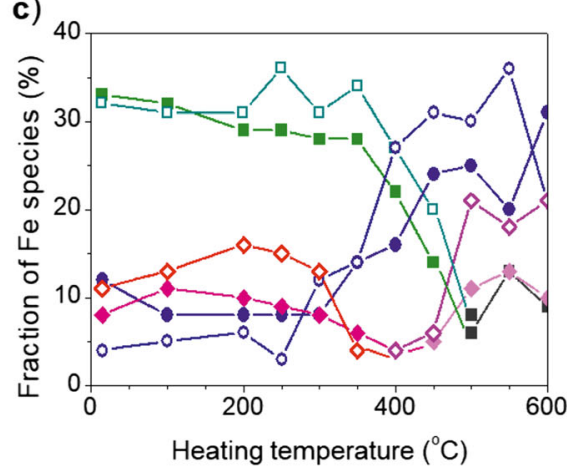

Fig. 5 Plots of the a) isomer shift (IS), b) quadrupole splitting (QS) and c) fraction of Fe species visible on Mössbauer spectrum of AlCel2, as function of heating temperature. Errors bars are smaller than the symbols. The lines indicate the trends of the data and act as a guide to the eye 

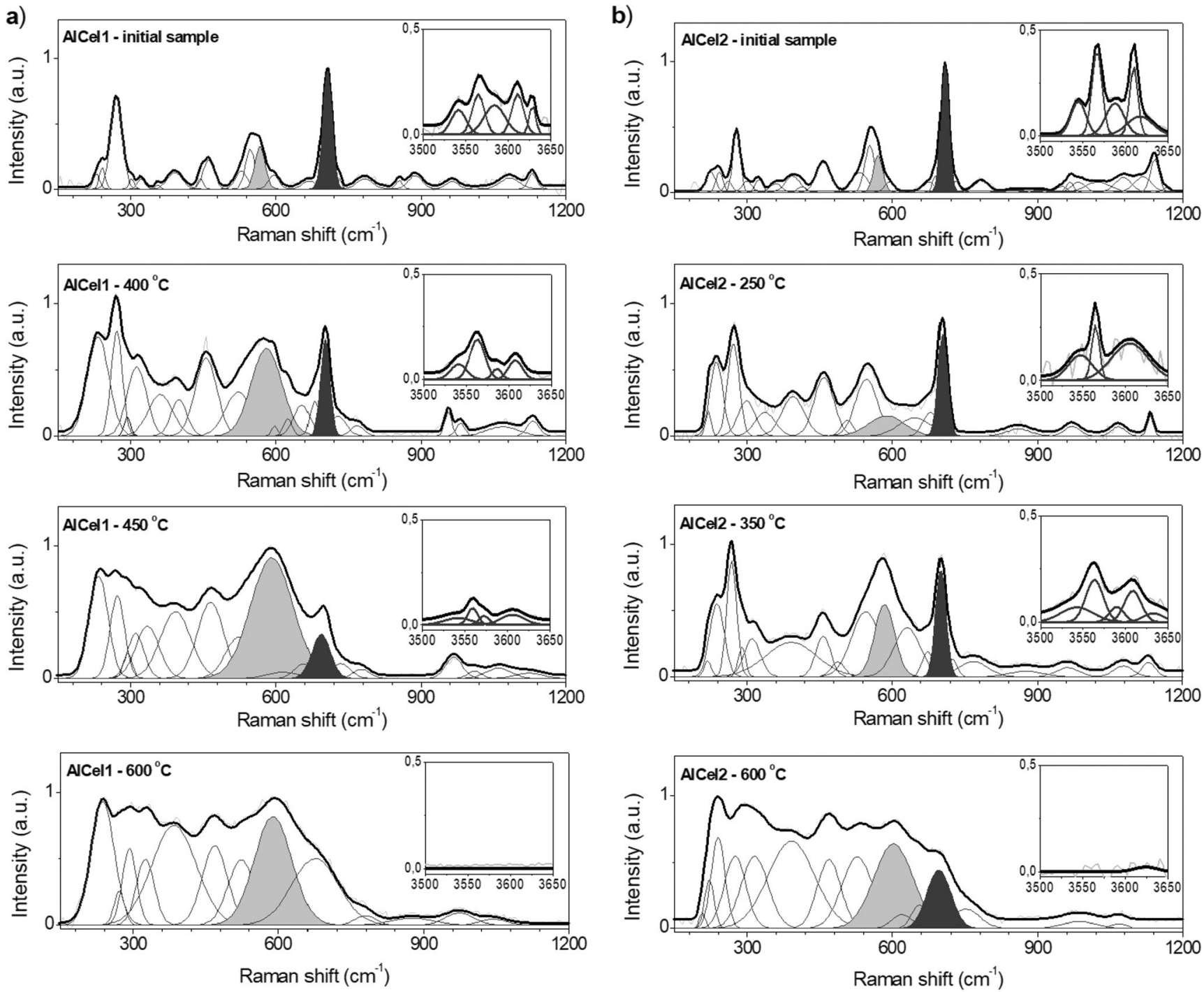

Fig. 6 Raman spectra of the initial sample of aluminoceladonites as well as collected at different temperatures of sample obtained for a) AlCell (left column) and for b) AlCel2 (right column); the zone of hydroxyl stretching are added as insert. Bands that are highlighted dark grey

Here, huge differences were found in the position of bands and their intensities in analysis of the $750-500 \mathrm{~cm}^{-1}$ range differences linked to the molecular vibration within tetrahedral and octahedral sheets (Fig. 6). For the record, the bands centred in between 710 and $690 \mathrm{~cm}^{-1}$ correspond to the overlapping signal of the stretching vibration of aluminum in tetrahedral and octahedral coordination as well as nonbridging and bridging oxygen in relation to the $\mathrm{A}_{\mathrm{g}}$ symmetry mode (McKeown et al. 1999). The appearance of the band between 690 and $600 \mathrm{~cm}^{-1}$ in turn may originate from the translational modes of i) nonbridging oxygen in the yz plane, ii) bridging oxygen in the yz plane as for the $\mathrm{A}_{\mathrm{g}}$ symmetry mode and iii) non-bridging oxygen in the $\mathrm{xz}$ plane as for the $\mathrm{B}_{\mathrm{g}}$ symmetry mode (McKeown et al.1999; Wang et al. 2015). Similarly, well-defined bands located at $600-500 \mathrm{~cm}^{-1}$ derived from the overlapping signal of ions occupying the tetrahedral as

correspond to the overlapping signals of tetrahedral and octahedral units, and bands that are highlighted light grey represent vibrations of aluminum-iron octahedrons and tetrahedrons

well as octahedral coordination. Tetrahedrally-coordinated ions are involved in the bending motion related to the xy plane ( $\mathrm{A}_{\mathrm{g}}$ and $\mathrm{B}_{\mathrm{g}}$ symmetry mode), while octahedrally-coordinated ions bending motion in the translational modes in the xz plane (McKeown et al. 1999). Based on temperature-dependent data, bands located at $549 \mathrm{~cm}^{-1}$ (AlCel1) or $553 \mathrm{~cm}^{-1}$ (AlCel2) in the initial samples were shifted, respectively, towards lower frequencies and are found at $523 \mathrm{~cm}^{-1}$ and $544 \mathrm{~cm}^{-1}$ in the samples annealed at $400{ }^{\circ} \mathrm{C}$ and $350{ }^{\circ} \mathrm{C}$, respectively. At the same time, an increase of full width at half maximum (FWHM) suggests strong molecular reorganization due to the heating. It is notable that those alterations correlate quite well with modifications within the hydroxyl group region and within tetrahedral sheets. This may suggest that the decrease in the hydrogen bonding scheme induced simultaneous rotation of tetrahedral- and octahedral units. Furthermore, the 
Table 2 Raman bands positions (in $\mathrm{cm}^{-1}$ ) obtained at selected temperatures for investigated aluminoceladonite samples and assignments. M octahedral / tetrahedral ion

\begin{tabular}{|c|c|c|c|c|c|c|c|c|}
\hline \multirow[t]{2}{*}{ Band assignment ${ }^{*}$} & \multicolumn{4}{|c|}{ AlCel1 } & \multicolumn{4}{|c|}{ AlCel2 } \\
\hline & RT & $400{ }^{\circ} \mathrm{C}$ & $450^{\circ} \mathrm{C}$ & $600{ }^{\circ} \mathrm{C}$ & RT & $250{ }^{\circ} \mathrm{C}$ & $350{ }^{\circ} \mathrm{C}$ & $600{ }^{\circ} \mathrm{C}$ \\
\hline \multirow[t]{5}{*}{ Hydroxyl stretching } & 3627 & 3608 & 3607 & & 3620 & 3604 & 3635 & 3626 \\
\hline & 3608 & 3586 & 3573 & & 3609 & 3565 & 3610 & \\
\hline & 3582 & 3560 & 3556 & & 3588 & 3547 & 3592 & \\
\hline & 3564 & 3536 & 3535 & & 3567 & & 3563 & \\
\hline & 3541 & & & & 3542 & & 3544 & \\
\hline \multirow[t]{7}{*}{$\mathrm{Si}-\mathrm{O}$ stretching } & 1130 & 1130 & 1127 & 1046 & 1144 & 1130 & 1132 & 1072 \\
\hline & 1083 & 1064 & 1060 & 970 & 1113 & 1067 & 1076 & 992 \\
\hline & 964 & 980 & 1011 & & 1075 & 968 & 961 & \\
\hline & & 945 & 969 & & 1024 & & & \\
\hline & & & & & 983 & & & \\
\hline & & & & & 965 & & & \\
\hline & & & & & 945 & & & \\
\hline \multirow[t]{3}{*}{$\mathrm{M}_{(\mathrm{Oct}, \mathrm{Tet})}-\mathrm{OH}$ bending } & 888 & 761 & 776 & 873 & 896 & 858 & 883 & 754 \\
\hline & 852 & & & 779 & 850 & & 878 & \\
\hline & 786 & & & & 783 & & 766 & \\
\hline $\mathrm{Si}-\mathrm{O}$ stretching & 730 & 731 & 734 & 676 & 732 & 704 & 723 & 697 \\
\hline \multirow[t]{3}{*}{$\mathrm{Al}_{(\mathrm{Oct}, \text { Tet })}-\mathrm{O}$} & 706 & 702 & 694 & & 708 & 681 & 700 & 659 \\
\hline & 685 & 679 & 654 & & 690 & 647 & 679 & \\
\hline & 671 & 646 & & & 671 & & 632 & \\
\hline \multirow{6}{*}{$\begin{array}{l}\mathrm{O}-\mathrm{M}_{(\mathrm{Oct}, \mathrm{Tet})} \mathrm{O} \\
\text { and } \mathrm{Si}-\mathrm{O}-\mathrm{M}\end{array}$} & 600 & 588 & 587 & 589 & 597 & 589 & 585 & 601 \\
\hline & 567 & 580 & 522 & 522 & 575 & 546 & 544 & 529 \\
\hline & 549 & 523 & 462 & 469 & 553 & 506 & 490 & 462 \\
\hline & 528 & 457 & & & 533 & 456 & 457 & \\
\hline & 462 & & & & 445 & & & \\
\hline & 440 & & & & 414 & & & \\
\hline \multirow[t]{7}{*}{ External modes } & 390 & 399 & 387 & 382 & 397 & 393 & 387 & 386 \\
\hline & 354 & 316 & 333 & 324 & 322 & 339 & 309 & 314 \\
\hline & 319 & 272 & 307 & 282 & 299 & 299 & 290 & 278 \\
\hline & 303 & 238 & 277 & 237 & 276 & 272 & 266 & 235 \\
\hline & 269 & & 235 & & 259 & 234 & 236 & 218 \\
\hline & 242 & & & & 241 & 219 & 214 & \\
\hline & 227 & & & & 224 & & & \\
\hline
\end{tabular}

* Band assignment according to Ospitali (2008) and Zviagina (2020)

$\mathrm{RT}=$ room temperature

octahedral positions are not fully charge-balanced due to isomorphic substitutions occurring between $\mathrm{Al}^{3+}, \mathrm{Fe}^{3+}, \mathrm{Mg}^{2+}$ and $\mathrm{Fe}^{2+}$ that are atypical for celadonite micas. As a result, the temperature may additionally intensify variable structural effects by introducing structural point defects into the crystal structure, as is especially well seen in the case of AlCell where many new low intensity bands appear on the Raman spectrum (Fig. 6).

\section{X-ray photoelectron spectroscopy}

One of the most powerful direct methods for investigating electronic structure, chemical bonds, and the nearest surroundings of atoms in substances is X-ray photoelectron spectroscopy. As XPS signals arise from within about $1-10 \mathrm{~nm}$ of the outermost surface layers of investigated samples (Elmi et al. 2016), this method is generally treated as a surface sensitivity method. Discrepancies, e.g., apparent shifts of the photoelectron peaks, can be explained as due to selective attenuation of some signals (Bhattacharyya 1993). Shifts due to surface charging do not depend on the thickness of the sample, but on whether or not there is an adsorbed layer on the mica surface that reduces the charging and, hence, the shift is also reduced. Moreover, many solid systems can exhibit different compositions at their surfaces due to oxidation, layering, or other surface forces. However, the surface analysis of clay minerals is indeed representative of the overall bulk composition. This is to be expected since clay mineral layers should be of similar composition whether at the surface or in the center of an aggregate. Therefore, the interpretation of the XPS spectra of the investigated aluminoceladonite can provide information on the molecular environment, i.e., oxidation state, multiplet structure, chemical bonding, etc. with an error of $<10 \%$. This can enable visualization of cation arrangement in a layersilicate structure at high temperatures. Reference survey spectra obtained in a wide range of energies, and high-resolution 
core lines of $\mathrm{C} 1 \mathrm{~s}, \mathrm{O} 1 \mathrm{~s}, \mathrm{Si} 2 \mathrm{p}, \mathrm{Al} 2 \mathrm{p}, \mathrm{Fe} 2 \mathrm{p}$ and K2p, were recorded at room temperature. Then, the series of measurements in situ were performed at temperatures of 100, 300 and $550{ }^{\circ} \mathrm{C}$. Quantification of XPS spectra utilizing peak area and peak height sensitivity factor was possible thanks to the Multipak Physical Electronics application. The XPS core level spectra were fitted with Gaussian-Lorentzian functions. XPS spectra obtained in the region of the Si2p, Al2p, Fe2p, K2p and $\mathrm{O} 1 \mathrm{~s}$ core levels for the aluminoceladonite $\mathrm{AlCel} 2$ are shown on Fig. 8.

The Si2p spectrum should show a doublet branching ratio of $2: 1$ for Si $2 p_{3 / 2}$ to $\mathrm{Si} 2 \mathrm{p}_{1 / 2}$ with a spin-orbit splitting of about $1 \mathrm{eV}$ difference. Values of $\mathrm{Si} 2 \mathrm{p}$ binding energies show $\mathrm{Si}^{4+}$ in tetrahedral coordination (Bhattacharyya 1993; Biino and Gröning 1998; Elmi et al. 2014, 2016). These spectra in Fig. 8 present two $\operatorname{Si} 2 p(3 / 2,1 / 2)$ doublets. The silicon binding energy shows that different populations of silicon correlate with substitutions in the tetrahedral sheet. A lower Si2p binding energy may result from a negative charge increase on the silicate framework as a result of $\mathrm{Si}^{4+}$ replacement by $\mathrm{Al}^{3+}$. Our results indicate that the tetrahedral sheet contains only $\mathrm{Si}$ in tetrahedral coordination with some $\mathrm{Al}^{3+}$ substitution. On the basis of the area ratio of $\mathrm{Si} 2 \mathrm{p}$ components, the ratio of $\mathrm{Si}^{4+}$ in tetrahedral coordination to $\mathrm{Al}^{3+}$ can be calculated; for AlCel2 this ratio is $72 / 28$. Because, the Al2p spectra have evident asymmetry in peak shape, they were decomposed into two Al2p doublets (Fig. 8). The obtained Al binding energy value is very close to both fourfold and sixfold coordination. However, an octahedral sheet must compensate for the charge of two relatively negative and adjacent tetrahedral sheets. The positive nature of the octahedral sheet coupled with the relatively negative silicate sheet results in more ionic Al-O bonds. The enhanced ionicity of the Al-O bond may be reflected in the relatively higher $\mathrm{Al} 2 \mathrm{p}$ binding energy value. Also, the presence of $\mathrm{OH}$ and/or $\mathrm{F}$ enhances the positive character of the $\mathrm{Al}$ resulting in a moderate increase in the Al2p binding energy (Barr et al. (1997)). That is why the $\mathrm{Al} 2 \mathrm{p}_{3 / 2}$ line located at a binding energy of $74.3 \mathrm{eV}$ relates to $\mathrm{Al}$ present in octahedral coordination, while the other line with a $\mathrm{BE}$ of $72.8 \mathrm{eV}$ arises from $\mathrm{Al}$ in tetrahedral coordination. The ratio of $\mathrm{Al}$ ions in tetrahedral to those in octahedral coordination is $27 / 73$ and is very close to those obtained for Si2p, supporting the correctness of our interpretation. Heating at $100{ }^{\circ} \mathrm{C}$ causes the decrease of the intensity lines located at $\mathrm{BE}$ of $102.8 \mathrm{eV}$ for the Si2p spectrum and $74.3 \mathrm{eV}$ for the Al2p spectrum. The calculated ratio of $\mathrm{Si}^{4+}$ in tetrahedral coordination to $\mathrm{Al}^{3+}$ which substituted $\mathrm{Si}^{4+}$ is $85 / 15$ and the ratio of $\mathrm{Al}$ ions in tetrahedral coordination to these in octahedral coordination is $14 / 86$. Heating at $300{ }^{\circ} \mathrm{C}$ does not lead to significant changes in the Si2p and Al2p spectra but, after heating at a temperature of $550{ }^{\circ} \mathrm{C}$, these spectra become almost symmetrical. The ratios of the intensity lines mentioned above for $\mathrm{Si}$ are $91 / 9$ at $300{ }^{\circ} \mathrm{C}$ and $97 / 3$ at $550{ }^{\circ} \mathrm{C}$. For the Al2p spectra, the obtained ratios amount to $12 / 88$ at $300{ }^{\circ} \mathrm{C}$ and $97 / 3$ at $550{ }^{\circ} \mathrm{C}$.
Potassium K2p has clearly spaced spin-orbit components (Fig. 8). Because, the K2p spectra have asymmetric peak shapes, they were decomposed into two K2p doublets. The $\mathrm{K} 2 \mathrm{p}_{3 / 2}$ binding energies at $294.4 \mathrm{eV}$ and $292.8 \mathrm{eV}$ are connected with the $\mathrm{K}^{+}$ions occupying interlayer sites between two 2:1 layers. The area ratio for the K2p doublets is $80 / 20$ for AlCel2, which results from the ratio of $\mathrm{K}^{+}$and $\mathrm{Ca}^{2+}$, respectively. Obtained the calcium content is too high and it may suggest that not only $\mathrm{Ca}^{2+}$ is substituting the $\mathrm{K}^{+}$in interlayer sites. This explanation is supported by $\mathrm{K} 2 \mathrm{p}$ spectra obtained at $100^{\circ} \mathrm{C}$ and $300^{\circ} \mathrm{C}$. As is seen on Fig. 8, the intensity line of $\mathrm{K} 2 \mathrm{p}_{3 / 2}$ with a binding energy of $294.4 \mathrm{eV}$ decreases and the area ratio for the doublets of K2p is $88 / 12$ at $100{ }^{\circ} \mathrm{C}$ and $95 / 5$ at $300^{\circ} \mathrm{C}$. This is also supported by XPS spectra of $\mathrm{O} 1 \mathrm{~s}$ regions obtained at the studied temperatures (Fig. 8). The O1s core-level line of the initial sample of dark-green celadonite comprises three separate peaks located at binding energies of 530.2, 531.7 and $533 \mathrm{eV}$, which can be related to the existence of different forms of oxygen bondings. The most intense line at a binding energy of $531.7 \mathrm{eV}$ is typical of lattice oxygen $\mathrm{O}^{2-}$ (Kloprogge and Wood, 2018) and the peak positioned at the highest binding energy of $533 \mathrm{eV}$ corresponds to hydroxyl oxygen $\mathrm{OH}^{-}$(Schingaro et al. 2013). The lowest intensity line at $530.2 \mathrm{eV}$ is due to the presence of O-Me bonds or $\mathrm{H}_{2} \mathrm{O}$ or the sum of both. The intensity of this line decreases after heating at $100^{\circ} \mathrm{C}$, which confirms the presence of a small amount of structural water in interlayer sites in the initial sample. Heating at $100^{\circ} \mathrm{C}$ also causes an increase of the intensity line corresponding to hydroxyl oxygen at a binding energy of $533 \mathrm{eV}$; this can be an effect of reaction of the water molecule $\mathrm{H}_{2} \mathrm{O}$ with oxygen $\mathrm{O}^{2-}$ creating $\mathrm{OH}^{-}$and $\mathrm{OH}$ groups. At $300{ }^{\circ} \mathrm{C}$, the ratio of the peaks located at binding energies of 531.7 and $533 \mathrm{eV}$ is almost the same but, at $550{ }^{\circ} \mathrm{C}$, the intensity of the hydroxyl oxygen line increases again.

The Fe2p spectra are characterised by doublet structures relating to the spin-orbit splitting between $2 p_{1 / 2}$ and $2 p_{3 / 2}$ states. In addition to the multiplet structures, shake-up satellite peaks arising from intrinsic energy losses when the photoelectron leaves the hosting atom, are present. Deconvolution of the Fe2p peak (Fig. 8) shows three main components. The first, a weaker component related to the $\mathrm{Fe}^{2+}$ valence state, is a doublet with binding energies $\mathrm{Fe} 2 \mathrm{p}_{3 / 2}=709.5 \mathrm{eV}$ and Fe2 $\mathrm{p}_{1 / 2}=$ $723 \mathrm{eV}$. The second, the highest component, is characteristic of the $\mathrm{Fe}^{3+}$ state observed as a multiplet with binding energies of the main component $\mathrm{Fe} 2 \mathrm{p}_{3 / 2}=712 \mathrm{eV}$ and $\mathrm{Fe} 2 \mathrm{p}_{1 / 2}=$ $725.5 \mathrm{eV}$. The third component at a binding energy $=$ $714.4 \mathrm{eV}$ is associated with the $\mathrm{Fe}^{3+}$ state. The $\mathrm{Fe}^{2+} / \mathrm{Fe}^{3+}$ ratio was determined to be $18 / 82$. The area ratio of the peaks at binding energies $=712 \mathrm{eV}$ and $714.2 \mathrm{eV}$ is $62 / 20$ and reflects the M2/M1 ratio of $\mathrm{Fe}^{3+}$ ions in octahedral positions. The $\sim 2 \mathrm{eV}$ distance between these components can reflect dehydroxylated sites. Small changes of the $\mathrm{Fe} 2 \mathrm{p}$ spectra are observed at $300{ }^{\circ} \mathrm{C}$ where the obtained $\mathrm{Fe}^{2+} / \mathrm{Fe}^{3+}$ ratio is $22 /$ 
78 and the ratio M2/M1 of $\mathrm{Fe}^{3+}$ ions is $56 / 22$, based on the area ratio of the $\mathrm{Fe} 2 \mathrm{p}$ lines. The main changes of the $\mathrm{Fe} 2 \mathrm{p}$ spectrum are observe at $550{ }^{\circ} \mathrm{C}$ where the binding energies of the peaks and their intensities change. All of the doublets observed are connected with $\mathrm{Fe}^{3+}$ ions. The two peaks located at 710.4 and $712.5 \mathrm{eV}$ can be associated with Fe in M1 sites and that with a binding energy of $714.2 \mathrm{eV}$ with a small contribution of iron in dimeric pyramid sites. The area ratio of peaks at bonding energies $=710.4 \mathrm{eV}$ and 712.5 to that at $714.2 \mathrm{eV}$ is $83 / 17$, which is similar to the ratio $87 / 13$ obtained from the Mössbauer studies at this temperature.

\section{Discussion}

TGA-DSC analysis reveal a small weight loss in the temperature range $50-150{ }^{\circ} \mathrm{C}$ that can result of the loss of bound molecular waters in the structure of the investigated aluminoceladonites. The endothermic events, areas of weight loss and the temperature-dependence of the unit-cell parameters indicate two-stage process of the dehydroxylation. The first stage of dehydroxylation takes place at a temperature of about $450{ }^{\circ} \mathrm{C}$ for $\mathrm{AlCel} 1$ and at a $350^{\circ} \mathrm{C}$ for $\mathrm{AlCel} 2$, when the adjacent $\mathrm{OH}$ groups are replaced with a single residual oxygen atom. In turn, temperature about $550{ }^{\circ} \mathrm{C}$ for AlCell and $500{ }^{\circ} \mathrm{C}$ for $\mathrm{AlCel} 2$ can be treated as the temperature where the second stage of dehydroxylation started. Finally, sample decomposition process starts at $736^{\circ} \mathrm{C}$.

The crystal-chemical models obtained due to ${ }^{57} \mathrm{Fe}$ Mössbauer spectroscopy (Tsipursky and Drits (1984); Dainyak et al. 2004, 2006, 2009, 2013; Zviagina et al. 2015) have shown that the values of the fitted quadrupole doublets $\mathrm{Fe}^{3+}$ and $\mathrm{Fe}^{2+}$ (visible on the Mössbauer spectra) may correspond to specific local cationic arrangements around these ions. Such cation distribution reconstructions can indicate random or ordered distribution of octahedral cations and can also display Fe clustering or domain structure. Due to above, the inner doublets with quadrupole splitting of $0.17 \mathrm{~mm} \mathrm{~s}^{-1}$ and $0.19 \mathrm{~mm} \mathrm{~s}^{-1}$ is assigned to $\mathrm{Fe}^{3+}$ with the three nearest $\mathrm{Fe}^{3+}$ ions. The quadrupole splitting of $0.49 \mathrm{~mm} \mathrm{~s}^{-1}$ and $0.54 \mathrm{~mm} \mathrm{~s}^{-1}$ reflects $\mathrm{Fe}^{3+}$ in the arrangement of $\mathrm{MgFe}^{2+} \mathrm{Fe}^{3+}$ and $2 \mathrm{AlFe}^{3+}$, respectively. The value of QS, which is $0.81 \mathrm{~mm} \mathrm{~s}^{-1}$, is close to the theoretical value responsible for $\mathrm{Fe}^{3+}$ in the $3 \mathrm{Al}$ arrangement. Though AlCell contains more $\mathrm{Al}$ ions than $\mathrm{AlCel} 2$, no doublets reflecting $\mathrm{Fe}^{3+}$ ions with $3 \mathrm{Al}$ arrangement are observed on the Mössbauer spectra, suggesting that $\mathrm{Al}$ ions are steadily ordered in octahedral sites. The large values of quadrupole splitting, i.e., 1.01, 1.29 and $1.44 \mathrm{~mm} \mathrm{~s}^{-1}$, associated with the trans-OH (M1) sites, are the consequence of $\mathrm{Fe}^{3+}$ in arrangements $\mathrm{AlMgFe}^{3+}$, $2 \mathrm{Fe}^{3+} \mathrm{Mg}$ and $2 \mathrm{AlMg}$, respectively. For AlCell, a higher proportion of components related to the $\mathrm{Al}$ environment than in AlCel2 is observed due to the higher $\mathrm{Al}$ content. A similar interpretation of the quadrupole splitting can be made for the local cation arrangements around $\mathrm{Fe}^{2+}$ ions. The smallest value of QS $\left(1.66 \mathrm{~mm} \mathrm{~s}^{-1}\right)$ is connected with the arrangement of $2 \mathrm{MgFe}^{2+}$ ions and the highest value $\left(2.77 \mathrm{~mm} \mathrm{~s}^{-1}\right)$ with $2 \mathrm{Fe}^{3+} \mathrm{Fe}^{2+}$. Intermediate QS reflect an almost similar arrangement, i.e., $2.23 \mathrm{~mm} \mathrm{~s}^{-1}$ is the result of $2 \mathrm{Fe}^{2+} \mathrm{Al}$ and $2.66 \mathrm{~mm} \mathrm{~s}^{-1}$ is the result of $\mathrm{AlMgFe}^{2+}$ local cation distributions. The above interpretation of Mössbauer spectra suggests that $\mathrm{Fe}^{3+}$ ions are not randomly located in the structure of the studied samples but in some position within the preferred neighbourhood.

According to so-performed analysis, a determined temperatures of the dehydroxylation by analysis of Mössbauer spectra turned out to be in good agreement with the XRD and DSC-TGA results. However, Mössbauer spectroscopy results indicate additional factors responsible for initiation of the process of dehydroxylation in the investigated aluminoceladonite. Namely, at temperature $\sim 350{ }^{\circ} \mathrm{C}$ for AlCell and at $300{ }^{\circ} \mathrm{C}$ for AlCel 2 the oxidation of $\mathrm{Fe}^{2+}$ to $\mathrm{Fe}^{3}$ started. In the oxidation process, the charge balance can be provided by the loss of protons; the occurrence of proton jumps between neighboring $\mathrm{OH}^{-}$groups and $\mathrm{O}^{2-}$ ions may be postulated. A proton jump or proton exchange causes a breakdown of the ordering of the $\mathrm{OH}^{-}$groups and the reduction of bond strength between $\mathrm{Fe}$ and hydroxyl. In facilitating loss of one of these groups, oxidation of $\mathrm{Fe}^{2+}$ may thus be associated with dehydroxylation or even initiate the process. The first stage of dehydroxylation takes place as the adjacent $\mathrm{OH}$ groups are replaced by a single residual oxygen atom. In this stage of dehydroxylation Fe ions do not migrate from M2 to M1 sites, but coordination numbers undergo change. This replacement of $\mathrm{OH}$ by $\mathrm{O}$ induces a change in the coordination of the octahedral sheet cations, becoming five instead of six. Additionally, above temperature $550{ }^{\circ} \mathrm{C}$ for AlCell and $500{ }^{\circ} \mathrm{C}$ for $\mathrm{AlCel} 2$, where second stage of dehydroxylation take place, on Mössbauer spectra appear doublet characteristic for $\mathrm{Fe}^{3+}$ in tetrahedral coordination. This can be the effect of the remodelling of some M1 coordination polyhedrons. The changing of coordination number from five to four is associated with detachment of an $\mathrm{OH}$ group or of $\mathrm{O}$ with the result that a dimeric pyramid can be formed.

An interesting supply of the previously mentioned techniques provides temperature-dependent Raman and XPS data. First of all, Raman spectra reveal huge differences in the position of bands and their intensities in the $750-500 \mathrm{~cm}^{-1}$ range were found (Fig. 6). More precisely, a gradual decrease of the intensity of the band centered at $706 \mathrm{~cm}^{-1}$ (AlCel1) and $708 \mathrm{~cm}^{-1}$ (AlCel2) was correlated with an increase of the band at $567 \mathrm{~cm}^{-1}$ (AlCel1) and $575 \mathrm{~cm}^{-1}$ (AlCel2). Additionally, the peak-fitting analysis was used to estimate the integrated intensity of two bands at $\sim 705 \mathrm{~cm}^{-1}$ and at $\sim 590 \mathrm{~cm}^{-1}$ and calculation of the integrated intensity ratio $\mathrm{I}_{590} / \mathrm{I}_{705}$ (Fig. $7 \mathrm{c}$ ). It is worth noting that this approach was purely hypothetical and 
not known from the literature. An interesting difference emerged, namely, the sample with higher aluminum started to undergo a structural reorganization at a higher temperature $\left(400^{\circ} \mathrm{C}\right)$ than the less aluminum-rich sample $\operatorname{did}\left(\sim 300^{\circ} \mathrm{C}\right)$. It may be speculated that the difference may reflect some change in the structural stability of the celadonite micas. What is more, a plot of temperature-dependent integral intensity revealed a jump of the $\mathrm{I}_{590} / \mathrm{I}_{705}$ values at temperatures of $\sim 500{ }^{\circ} \mathrm{C}$ may indicate a phase transition of celadonite into ferri-phlogopite or ferri-biotite. However, the appearance of potentially new phases was countered by the XRD and Mössbauer results. The correlation of the Raman data with the Mössbauer spectroscopy outcomes does raise the possibility of analyzing the contribution of $\mathrm{Fe}$ in octahedral sites in relation to temperature. The Mössbauer spectroscopy data suggest that the $\mathrm{I}_{590} / \mathrm{I}_{705}$ pattern may reflect the increase in occupancy of the M1 site with increasing temperature (Fig. 7). The observed maximum of the intensity ratio of $\mathrm{I}_{590} / \mathrm{I}_{705}$ at $550{ }^{\circ} \mathrm{C}$ for $\mathrm{AlCel} 1$ and $500{ }^{\circ} \mathrm{C}$ for $\mathrm{AlCel} 2$ indicates that the polyhedra have been transformed from six-coordinated into five-coordinated polyhedra. Afterwards, a slow decrease in the curves with temperature (Fig. 7c) reflects the migration of cations from cis-sites to trans-sites. Those data are in good agreement with results obtained from the XRD analysis and reflect the conclusions taken from the Mössbauer data.

Secondly, X-ray photoelectron spectroscopy were applied to look more precisely on the chemical environment and follow the impact of temperature on the modification of chemical states. According to XPS data, the two Si2p $(3 / 2,1 / 2)$ doublets indicate that the tetrahedral sheet contains only $\mathrm{Si}$ in tetrahedral coordination with some $\mathrm{Al}^{3+}$ substitution. On the basis of the area ratio of $\mathrm{Si} 2 \mathrm{p}$ components, the ratio of $\mathrm{Si}^{4+}$ in tetrahedral coordination to $\mathrm{Al}^{3+}$ is $72 / 28$. On the other hand, the Al2p spectrum indicate that $\mathrm{Al}$ ions are present in octahedral and in tetrahedral coordination in structure of AlCel2. The ratio of $\mathrm{Al}$ ions in tetrahedral to those in octahedral coordination is $27 / 73$ and is very close to those obtained for Si2p. Heating the sample at $100{ }^{\circ} \mathrm{C}$ causes the change of the intensity lines for the Si2p and for the Al2p. This observation confirms the XRD results which indicated the loss of bound molecular waters in the structure of the AlCel 2 close to this temperature. After heating at a temperature of $550{ }^{\circ} \mathrm{C}$ these spectra become almost symmetrical. The ratio of the intensity lines mentioned above for $\mathrm{Si}$ is $97 / 3$ and for $\mathrm{Al}$ is $97 / 3$, at $550{ }^{\circ} \mathrm{C}$. These results suggest that at higher temperatures, the $\mathrm{Al}$ cations are mostly located in octahedral sites what confirm conclusions from XRD, Raman and Mössbauer analysis.

The K2p spectrum of initial sample AlCel2 were decomposed into two doublets. The origin of the extra K2p doublet is not well understood. On the basis of the chemical analysis, it might be concluded that it is the result of calcium substitution modifying the chemical environment in the interlayer configuration of the micas. The area ratio for the mentioned above components is $80 / 20$, which results from the ratio of $\mathrm{K}^{+}$and $\mathrm{Ca}^{2+}$, respectively. However, the calcium content is too high compared to the results of the chemical analysis. It may suggest that not only $\mathrm{Ca}^{2+}$ is substituting the $\mathrm{K}^{+}$in interlayer sites but that in these sites also, a small amount of structural water is present. This explanation is supported by $\mathrm{K} 2 \mathrm{p}$ spectra obtained at $100{ }^{\circ} \mathrm{C}$ and $300{ }^{\circ} \mathrm{C}$. The intensity of extra doublet decreases during the heating and the area ratio for the doublets of $\mathrm{K} 2 \mathrm{p}$ is $88 / 12$ at $100^{\circ} \mathrm{C}$ and $95 / 5$ at $300{ }^{\circ} \mathrm{C}$. This is the result of dehydration of interlayer water from inner surfaces with the increase in temperature. This is also supported by XPS spectra of O1s regions obtained at the studied temperatures.

The $\mathrm{Fe}^{2+} / \mathrm{Fe}^{3+}$ ratio, based on the area ratio of $\mathrm{Fe} 2 \mathrm{p}$, was determined to be $18 / 82$, in very good agreement with the chemical analysis and with the Mössbauer results. Also, the area ratio of the peaks connected with $\mathrm{Fe}^{3+}$ is $62 / 20$ and reflects the M2/M1 ratio of $\mathrm{Fe}^{3+}$ ions in octahedral positions. The main changes of the Fe2p spectrum are observe at $550{ }^{\circ} \mathrm{C}$ where all of the doublets observed are connected with $\mathrm{Fe}^{3+}$ a)

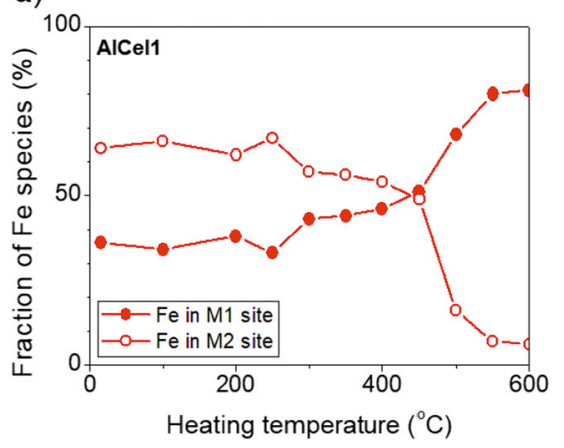

b)

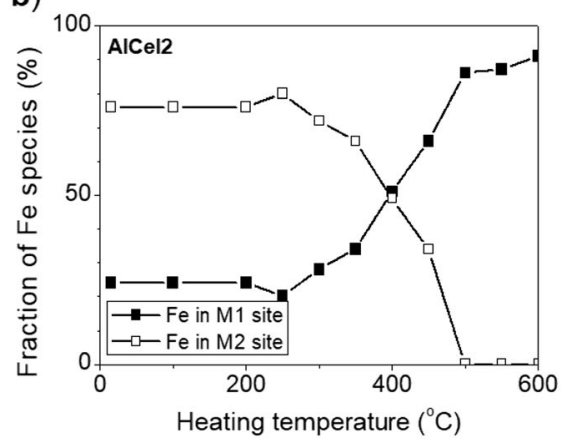

c)

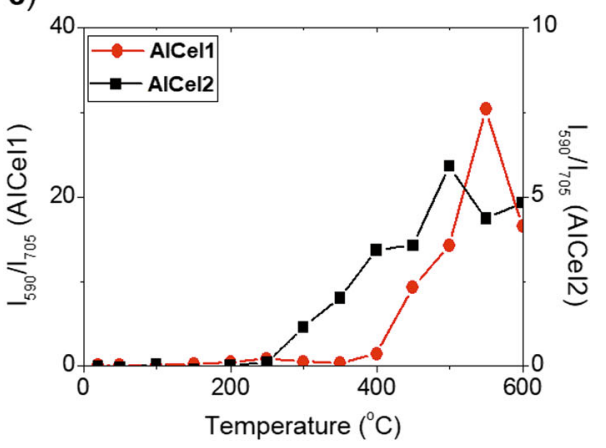

Fig. 7 Plots of temperature dependence of average fraction of Fe species in M1 and M2 sites obtained from Mössbauer measurements for a) AlCel1 and b) AlCel2 and c) integral intensity ratio between bands centred at $\sim 590$ and $\sim 705 \mathrm{~cm}^{-1}$ versus temperature obtained from
Raman results. Note: values of fraction of Fe species in octahedral sites were obtained after cooling the sample from high to room temperature and the lines indicate only the trends of the data 
a)

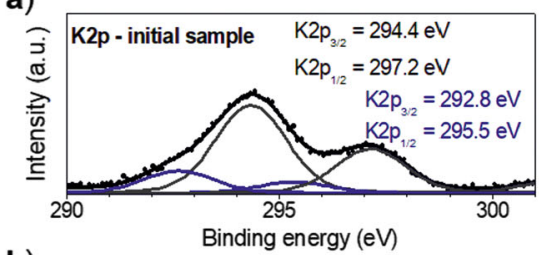

b)

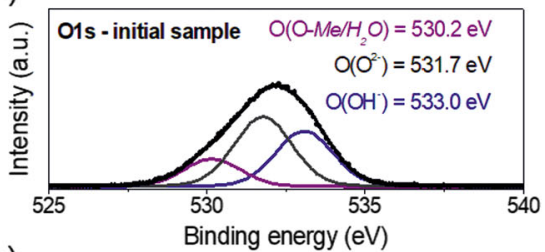

c)

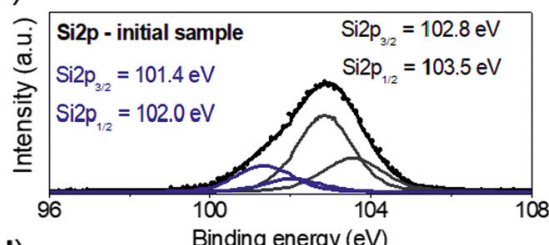

d)

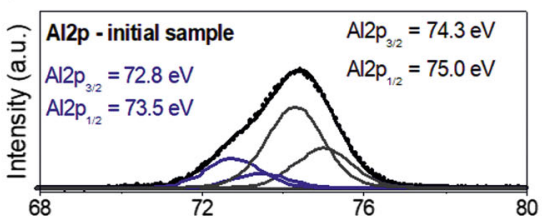

e)

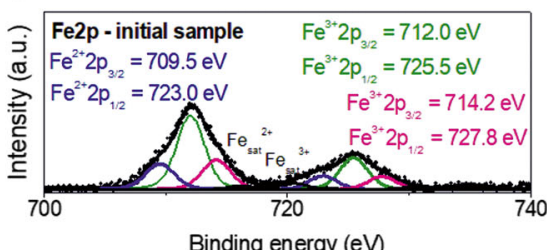

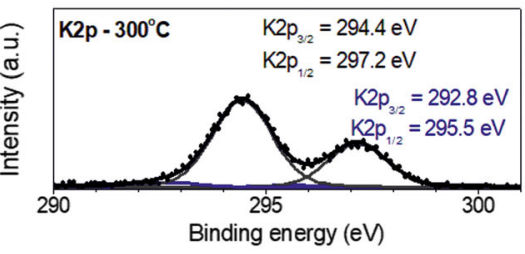
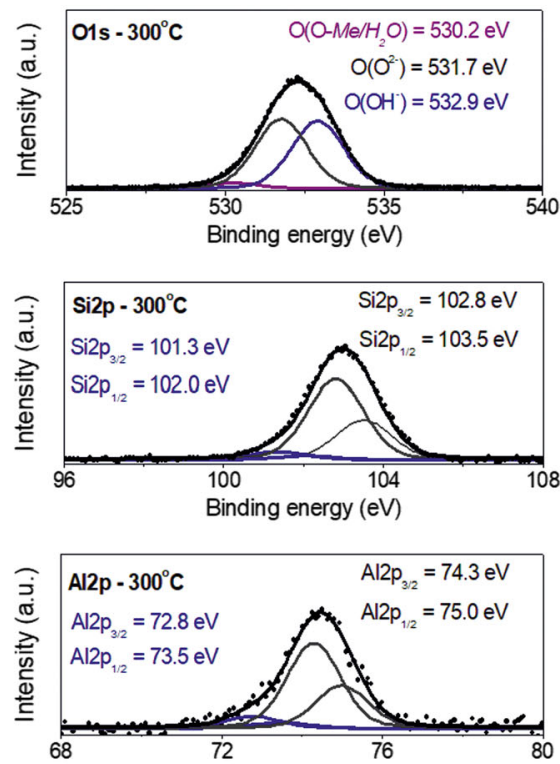

Binding energy (eV)

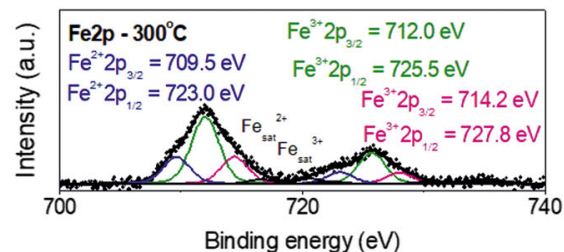

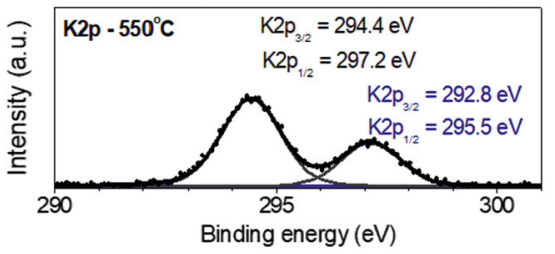
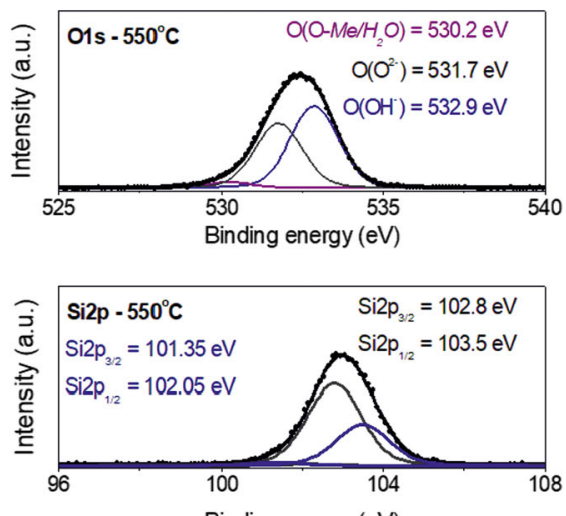

Binding energy (eV)

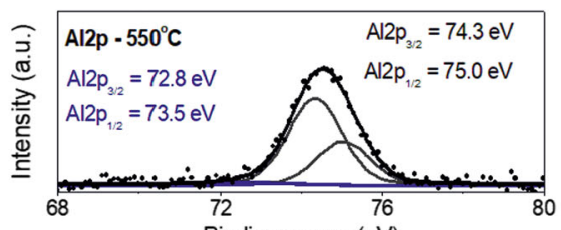

Binding energy (eV)

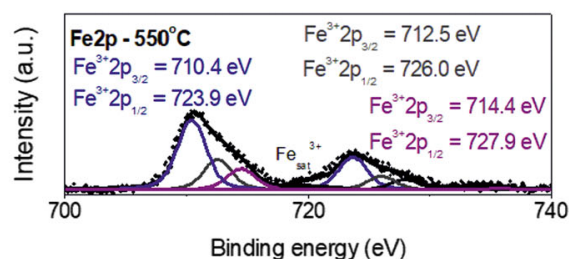

Fig. 8 XPS spectra showing (in rows) the a) Si2p, b) A12p, c) K2p, d) O1s and f) Fe2p regions with relative peak deconvolutions obtained for AlCel2 initial sample as well as collected at temperature $300^{\circ} \mathrm{C}$ and $550{ }^{\circ} \mathrm{C}$. The binding energy value (BE) of each component is presents on the spectrum

ions. The two peaks can be associated with $\mathrm{Fe}$ in $\mathrm{M} 1$ sites and one, with a small contribution, of iron in dimeric pyramid sites. Relationship of these $\mathrm{Fe} 2 \mathrm{p}$ peaks with specific Fe sites in structure of aluminoceladonite or more generally in structure of layer silicates was showed first time. The area ratio two first peaks to the last one is $83 / 17$, which is similar to the ratio $87 / 13$ obtained from the Mössbauer studies at this temperature.

\section{Conclusions}

We show that all of the measured data show that the aluminoceladonite with a higher aluminum content started to structurally reorganize at a higher temperature range than the less aluminum-rich sample. The oxidation of $\mathrm{Fe}^{2+}$ to $\mathrm{Fe}^{3+}$ ions started at $\sim 350{ }^{\circ} \mathrm{C}$ for the Al-richer sample and at $300{ }^{\circ} \mathrm{C}$ for the other. This process may be associated with, or even initiate, dehydroxylation. Up to a temperature of $\sim 500^{\circ} \mathrm{C}$, cation migration in the octahedral sheet is not seen. Based on Mössbauer results, visible changes in the coordination numbers of polyhedrons occurred; octahedrally-coordinated $\mathrm{Fe}^{3+}$ occupying M2 sites becomes 5 -coordinated. This temperature can be viewed as the second stage of dehydroxylation. Based on Raman data, the proposed temperature-dependent integral intensity ratio between bands centred at $\sim 590$ and $750 \mathrm{~cm}^{-1}\left(\mathrm{I}_{590} /\right.$ $\mathrm{I}_{705}$ ) clearly indicates the temperature at which sixcoordinated polyhedra are transformed to five-coordinated. Above $\sim 500{ }^{\circ} \mathrm{C}$, cation migration from former cis-sites to former trans-sites take place. Changing of coordination number from five into four is associated with the detachment of $\mathrm{OH}$ or $\mathrm{O}$ and, as a result, dimetric pyramids can be formed. 
Electronic supplementary material The online version of this article (https://doi.org/10.1007/s00710-021-00753-z) contains supplementary material, which is available to authorized users.

Acknowledgments Constructive comments of two anonymous reviewers and journal editor Anton Beran are gratefully acknowledged.

This work was supported by the National Science Centre, Poland (grant DEC- 2018/02/X/ST10/00662).

Open Access This article is licensed under a Creative Commons Attribution 4.0 International License, which permits use, sharing, adaptation, distribution and reproduction in any medium or format, as long as you give appropriate credit to the original author(s) and the source, provide a link to the Creative Commons licence, and indicate if changes were made. The images or other third party material in this article are included in the article's Creative Commons licence, unless indicated otherwise in a credit line to the material. If material is not included in the article's Creative Commons licence and your intended use is not permitted by statutory regulation or exceeds the permitted use, you will need to obtain permission directly from the copyright holder. To view a copy of this licence, visit http://creativecommons.org/licenses/by/4.0/.

\section{References}

Barr T, Seal S, Wozniak K, Klinowaki J (1997) ESCA studies of the coordination state of aluminium in oxide environments. J Chem Soc Faraday Trans 93:181-186

Biino G, Gröning P (1998) Cleavage mechanism and surface chemical characterization of phengitic muscovite and muscovite as constrained by X-ray photoelectron spectroscopy. Phys Chem Min 25:168-181

Bhattacharyya K (1993) XPS study of mica surfaces. J Electron Spectros Relat Phenomena 63:289-306

Dainyak L, Drits V, Lindgreen H (2004) Computer simulation of octahedral cation distribution and interpretation of the Mössbauer $\mathrm{Fe}^{2+}$ components in dioctahedral trans-vacant micas. Eur J Mineral 16: 451-468

Dainyak L, Zviagina B, Rusakov V, Drits V (2006) Interpretation of the nontronite-dehydroxylate Mössbauer spectrum using EFG calculations. Eur J Mineral 18:753-764

Dainyak L, Rusakov V, Sukhorukov I, Zviagina B, Drits V(2009) An improved model for the interpretation of Mössbauer spectra of dioctahedral 2:1 trans-vacant Fe-rich micas: refinement of parameters. Eur J. Mineral 21(5):995-1008.

Dainyak L, Rusakov V, Sukhorukov I, Drits V (2013) Octahedral cation distribution in glauconites from southern Urals by combination of crystal-chemical model and quasi-continuous model-independent quadrupole splitting distributions (QSD) fitted to their Mössbauer spectra. Eur J Mineral 25(3):405-414

Drits V, Besson G, Muller F (1995) An improved model for structural transformations of heated-treated aluminous dioctahedral 2:1 layer silicates. Clays Clay Mineral 43(6):718-731

Drits V, Dainyak G, Muller F, Besson G, Manceaut A (1997) Isomorphous cation distribution in celadonites, glauconites and $\mathrm{Fe}-$ illites determined by infrared, Mössbauer and EXAFs spectroscopies. Clay Miner 32:153-179

Drits V, McCarty D, Zviagina B (2006) Crystal-chemical factors responsible for the distribution of octahedral cations over trans- and cissites in dioctahedral 2:1 layer silicates. Clays Clay Mineral 54(2): $131-152$

Elmi C, Brigatti M, Guggenheim S, Pasquali S, Montecchi M, Nannarone S (2014) Crystal chemistry and surface configurations of two polylithionite-1M crystals. Am Mineral 99:2049-2059
Elmi C, Guggenheim S, Gier R (2016) Surface crystal chemistry of phyllosilicates using X-ray photoelectron spectroscopy: a review. Clays Clay Mineral 64:537-551

Hradila D, Grygara T, Hradilova J, Bezdicka P (2003) Clay and iron oxide pigments in the history of painting. Appl Clay Sci 22: 223-236

Kloprogge J.T, Wood B (2018) X-ray photoelectron spectroscopy and Raman microscopy of a ferroan platinum crystal from the Kondyor Massif, Russian Far East. Spectrosc Lett 52(1) 21:43-48. https://doi. org/10.1080/00387010.2018.1546745

McKeown D, Bell M, Etz E (1999) Vibrational analysis of the dioctahedral mica: 2M $\mathrm{M}_{1}$ muscovite. Am mineral 84:1041-1048. 0003-004X/99/0708-1041\$05.00

Moretto L, Orsega E, Mazzocchin G (2011) Spectroscopic methods for the analysis of celadonite and glauconite in Roman green wall paintings. J Cult Herit 12:384-391

Muller F, Plançon A, Drits V, Besson G (1998) Modelisation of X-ray powder diffraction patterns for the study of heat-treated Fe-rich dioctahedral 2:1 layer silicates. J Phys IV France 8:91-98

Muller F, Plançon A, Besson G, Drits V (1999) Nature, proportion and distribution of stacking faults in celadonite minerals. Mater Struct 6(2):129-134

Muller F, Drits V, Plançon A, Besson G (2000a) Dehydroxylation of $\mathrm{Fe}^{3+}$, mg-rich dioctahedral micas: (I) structural transformation. Clay Miner 35(3):491-504

Muller F, Drits V, Tsipursky S, Plançon A (2000b) Dehydroxylation of $\mathrm{Fe} 3+$, mg-rich dioctahedral micas: (II) cation migration. Clay Miner 35(3):505-514

Muller F, Drits V, Plançon A, Robert J-P (2000c) Structural transformation of 2:1 dioctahedral layer silicates during dehydroxylationrehydroxylation reactions. Clay Clay Miner 48:572-585

Murad E, Fabris J (2010) Kaolin mining and beneficiation: the role of iron. J Phys: Conference Series 217:012066. https://doi.org/10. 1088/1742-6596/217/1/012066

Ospitali F, Bersani D, Di Lonardo G, Lottici P (2008) 'Green earths': vibrational and elemental characterization of glauconites, celadonites and historical pigments. J Raman Spectrosc 39:10661073

Povarennykh A (1978) The use of infrared for the determination of minerals. Am Mineral 63:956-959

Prisecaru I (2009-2016) WMOSS4 Mössbauer spectral analysis software. Available at www.wmoss.org ()

Rancourt D (1994) Mössbauer spectroscopy of minerals II. Problem of resolving cis and trans octahedral $\mathrm{Fe}^{2+}$ sites. Phys Chem Miner 21: 250-257

Rieder M, Cavazzini G, D’Yakonov Y, Frank-Kameneckii V, Gottardi G, Geggenheim S, Koval P, Müller G, Neiva A, Radoslovich E, Robert J, Sassi F, Takeda H, Weiss Z, Wones D (1998) Nomenclature of the micas. Can Mineral 36:905-912

Savko K, Piliugin S, Bazikov N (2015) Experimental data for hightemperature decomposition of natural celadonite from banded iron formation. Chin J Geochem 34(4):507-514

Schingaro E, Lacalamita M, Scordari F, Mesto E (2013) 3T-phlogopite from Kasenyi kamafugite (SW Uganda): EPMA, XPS, FTIR, and SCXRD study. Am Mineral 98:709-717

Tischendorf G, Forster H, Gottesmann B, Rieder M (2007) True and brittle micas: composition and solid-solution series. Mineral Mag 71(3):285-320

Tsipursky S, Drits V (1984) The distribution of octahedral cations in the 2:1 layers of dioctahedral smectites studied by oblique-texture electron diffraction. Clay Miner 19:177-193

Tsipursky S, Kameneva M, Drits V (1985) Structural transformation of $\mathrm{Fe}^{3+}$ containing dioctahedral 2:1 phyllosilicates in the course of dehydroxylation. In J. Konta, Ed., proceedings of the 5th meeting of the European clay groups, Prague, 569-577 
Wang A, Freeman J, Jolliff B (2015) Understanding the Raman spectral features of phyllosilicates. J Raman Spectrosc 46(10):829845

Zviagina B, McCarty D, Środoń J, Drits V (2004) Interpretation of infrared spectra of dioctahedral smectites in the region of $\mathrm{OH}$-stretching vibrations. Clays Clay Mineral 52(4):399-410. 0.1346/ CCMN.2004.0520401

Zviagina B, Sakharov B, Drits V (2007) X-ray diffraction criteria for the identification of trans- and cis-vacant varieties of dioctahedral micas. Clays Clay Mineral 55(5):467-480

Zviagina B, Drits V, Środoń J, McCarty D, Dorzhieva O (2015) The illitealuminoceladonite series: distinguishing features and identification criteria from X-ray diffraction and infrared spectroscopy data. Clays Clay Mineral 63(5):378-394

Zviagina B, Drits V, Dorzhieva O (2020) Distinguishing features and identification criteria for K-Dioctahedral $1 \mathrm{M}$ micas (IlliteAluminoceladonite and Illite-Glauconite-Celadonite series) from middle-infrared spectroscopy data. Minerals 10:153

Publisher's note Springer Nature remains neutral with regard to jurisdictional claims in published maps and institutional affiliations. 